\title{
Krievijas intervence Krimā: vērtējums no starptautisko tiesību viedok!̣a
}

\author{
Dr. iur. Jänis Grasis \\ Rīgas Stradiña universitāte, Juridiskā fakultāte, \\ Tiesību zinātñu katedra, Latvija
}

\section{Kopsavilkums}

Rakstā apskatīta Krievijas Federācijas militārā invāzija Krimā 2014. gada pavasarī un tā analizēta no starptautisko tiesību viedokḷa, izmantojot normatīvo aktu analīzes metodi. Pētījuma rezultātā tiek atzīts, ka Krievijas Federācijas aktivitātes Krimā ir vērtējamas kā kara noziegums.

Atslēgvārdi: Krima, “zaḷie cilvēciṇi”, agresija, kara noziegums.

2014. gada pavasarī Ukrainā notika tas, ko Eiropa nebija piedzīvojusi kopš pagājušā gadsimta trīsdesmitajiem gadiem. Krievija 2014. gada februāra beigās okupēja Ukrainai piederošo Krimas pussalu, bet martā to anektēja. Krimas okupācijā tika iesaistīti karavīri bez pazīšanas zīmēm, kas liecinātu par vinu piederību kādas valsts armijai. Plašsaziṇas līdzekḷi šos karavīrus sāka dēvēt par “zaḷajiem cilvēciṇiem”. Krievijas prezidents Vladimirs Putins jau 2014. gada 17. aprīlī televīzijas tiešajā pārraidē atzina, ka "zalıie cilvēciṇi”, kas sevi sauca par vietējās pašaizsardzības spēkiem, patiesībā bija Krievijas karavīri.

Oficiāli par "Krimas atgūšanas" operācijas sākumu tiek uzskatīts 2014. gada 20. februāris, jo tieši šis datums iegravēts Krievijas Aizsardzības ministrijas medal̄ās "Par Krimas atgūšanu”. Krimas okupācijas aktīvā daḷa sākās naktī no 26. uz 27. februāri, kad plkst. 4.30 Krimā tika izsēdināti 120 Krievijas karavīri. Viṇiem vēlāk tika pievienoti 1700 desantnieki, kurus pussalā nogādāja aviācija. Krievijas karavīri mēneša laikā "bez asinsizliešanas sagrāba svarīgākos civilos un militāros objektus", Ukrainas armijas karavīrus piespiežot padoties [6]. Krimas aneksija tika pabeigta ar Krievijas Federācijas prezidenta V. Putina rīkojumu [10].

Jau šogad, 2015. gada 15. martā, tika demonstrēta Krievijas dokumentālā filma “Krima. Ceḷš uz dzimteni”, kurā Krievijas prezidents lepni klāsta par izstrādāto plānu un specoperāciju Krimas aneksijas realizēšanai, kaut arī Putins iepriekš vienmēr noliedza Krievijas karaspēka līdzdalību Krimas aneksijā un karadarbībā Donbasā. 
Putina vārdu patiesumu apstiprināja arī bijušais Krievijas Federācijas Melnās jūras flotes komandieris admirālis Igors Kasatonovs, kurš šajā filmā norādīja, ka Krievijas bruṇoto spēku Melnās jūras flote 2014. gada februārī nodrošināja slepenu Krievijas specvienību nogādāšanu Krimā, kur tās nobloḳēja Ukrainas karaspēku. Admirālis norādīja, ka "Melnās jūras flote sagatavoja placdarmu, virsnieki zināja, kas notiek apkārt, kur ir izvietotas ukraiṇu armijas dal̦as, notikumu attīstības scenāriji tika izstrādāti kartēs. Tas ir, Melnās jūras flote ar saviem uzdevumiem tika galā. Tika nogādāti "pieklājīgie l̦audis", kas naktī no 27. uz 28. februāri ien̦ēma Krimas Augstāko padomi.” [6]

Kā vērtēt Krievijas Federācijas intervenci Krimā? Krievijas Federācija bija atzinusi eksistējošās Ukrainas valsts robežas šādos starptautisko tiesību dokumentos:

1) Alma-Atas 1991. gada 21. decembra deklarācijā, ar kuru likvidēja Padomju Sociālistisko Republiku Savienību (PSRS) un izveidoja Neatkarīgo Valstu Savienību (NVS); ar šo deklarāciju 11 valstis (bijušās 11 PSRS republikas, izṇemot trīs Baltijas valstis un Gruziju), kas izveidoja NVS, atzina un apñēmās ievērot citu valstu teritoriālo nedalāmību un esošo robežu nemainīgumu [8];

2) Budapeštas 1994. gada 4. decembra memorandā par drošỉbas garantijām, kurā Krievijas Federācija, Lielbritānijas un Ziemelīiijas Apvienotā Karaliste un Amerikas Savienotās Valstis sniedza Ukrainai drošības garantijas un Ukrainas eksistējošo robežu negrozāmību apmaiṇā pret kodolieroču izvešanu no šis valsts teritorijas [4]. Šo memorandu parakstīja Ukrainas prezidents L. Kučma, Krievijas Federācijas prezidents B. Jeḷcins, Apvienotās Karalistes premjerministrs Dž. Meidžors un ASV prezidents B. Klintons;

3) Krievijas un Ukrainas 1997. gada līgumā par Melnās jūras flotes izvietošanu Krimas ostās, kas aṭ̣āva turēt Krievijas kuguus Krimas ostās, kā arī uzturēties nozīmīgam skaitam Krievijas karavīru Krimā. Ar līgumu tika sadalìta bijusī PSRS Melnās jūras kara flote proporcijā 50:50. Lai gan pussalā saglabājās Krievijas Federācijas militārā klātbūtne, Krima un Sevastopole juridiski un teritoriāli palika Ukrainas sastāvā $[5,1]$. Lìgums 2010. gadā tika pagarināts uz nākamajiem 25 gadiem. Jebkurā gadījumā Krievijas spēku pārvietošanās vai to iespējamā palielināšana varēja notikt tikai pēc konsultācijām ar Ukrainas varas iestādēm.

Pārkāpjot šeit minētās vienošanās, Krievijas Federācija sāka palielināt tās bruṇotos spēkus Krimā bez Ukrainas piekrišanas, turklāt izvietoja tos ārpus militārajām bāzēm, aplencot Ukrainas armijas daḷas, pārn̦emot lidostas un varas iestāžu ēkas. Šāda rīcība radijja augsni Ukrainas varas iestāžu pārnememšanai, nomainot tās ar prokrieviskām struktūrām. No starptautisko tiesību viedokḷa šāda rīcība noteikti kvalificējama par militāro intervenci. Ārvalsts bruņotie spēki iekaroja svešu teritoriju, kaut arī tas notika bez neviena šāviena.

Saskaṇā ar ANO G̦enerālās Asamblejas 1974. gada 14. decembra rezolūcijas "Agresijas definīiija" 3. panta "a" apakšpunktu "Valsts bruṇoto spēku invāzija vai uzbrukums citā valstī, vai jebkura militārā okupācija, kaut arī îslaicīga, kas radusies no šādas invāzijas vai uzbrukuma, vai jebkura citas valsts teritorijas aneksija, pielietojot spēku", tiek 
uzskatīta par agresiju [2]. Saskaṇā ar Romas Starptautiskās krimināltiesas statūtu 5. panta 1. dalıas "d" apakšpunktu "agresija" ir uzskatāma par vissmagāko kara noziegumu [7]. Teritorijas sagrābšana ar militāru spēku ir tiesiska tikai tad, ja spēks pielietots saskaṇā ar starptautiskajām tiesībām, respektīvi, ne vienkārši pēc tā saucamajām uzvarētāju tiesībām, bet pašaizsardzības karā sodot agresoru. Svaigs piemērs tam ir Austrumprūsijas atṇemšana Vācijai un tās nodošana PSRS pēc Otrā pasaules kara [3]. Lai attaisnotu Krievijas Federācijas intervenci Krimā, Krievijas Federācijā pat ir parādījies jauns termins "Krimas tiesības" [9]. Tiek salīdzināts Kosovas precedents, lai pamatotu Krimas pievienošanu Krievijas Federācijai [9, 22-26]. Taču šeit ir viena liela atškirīiba. Kosovas gadỉjumā pret tās iedzīvotājiem tika veikts genocīds. Ne velti tika radìta Starptautiskā Krimināltiesa bijušajai Dienvidslāvijai (turpmāk tekstā SKTD), kas sauca pie kriminālatbildības personas, kas izdarïjušas smagus starptautisko humanitāro tiesību pārkāpumus bijušās Dienvidslāvijas teritorijā no 1991. gada. Krimas gadījumā pret tās iedzīvotājiem Ukrainas bruṇotie spēki vai kāda cita paramilitāra struktūra neveica vardarbību un nebija pat mazāko pazīmju, ka šāda vardarbība varētu tikt veikta. Tādējādi 2008. gada 17. februāra Kosovas Asamblejas pieñemtā Neatkarības deklarācija, kas notika pēc genocīda pret Kosovas tautu, tika atzìta visā civilizētajā pasaulē un neradīja precedenta tiesības [1].

Iepriekšminētā dēl neapšaubāmi var uzskatīt, ka no starptautisko tiesību viedokḷa Krievijas Federācijas īstenotā Krimas okupācija un aneksija ir kara noziegums, un jācer, ka nākotnē Krievijas iesaistītās amatpersonas tiks tiesātas par agresiju.

\section{Secinājums}

Pēc PSRS sabrukuma Krievijas Federācija bija atzinusi Ukrainas robežu neaizskaramību. Krievijas veiktā Krimas okupācija un aneksija noteikti ir kara noziegums saskaṇā ar Romas Starptautiskās krimināltiesas statūtiem.

\section{Russian Intervention in Crimea: Point of View from the International Law}

\section{Abstract}

The article provides overview of the military invasion of the Russian Federation in Crimea during the spring of 2014, analysing it from the point of view of the international law. The method of analysis of legal acts has been allpied. The provided conclusions prove that the activities of the Russian Federation in Crimea can be defined as a war crime.

Keywords: Crimea, "green man", agression, war crime. 


\section{Literatūra un avoti}

1. Advisory Opinion. Accordance with International Law of the Unilateral Declaration of independence in respect of Kosovo. July 22 ${ }^{\text {nd }}, 2010$. International Legal Materials, 2010; 49 (5).

2. ANO G̦enerālās Asamblejas 1974. gada 14. decembra rezolūcija Agresijas definìcija. Iegūts no: http://www.un-documents.net/a29r3314.htm [sk. 30.03.2015.].

3. Bojārs, J. Starptautiskās publiskās tiesības I. Rīga: Zvaigzne ABC, 297. lpp.

4. Budapest Memorandums on Security Assurances, 1994. Iegūts no: http://www.cfr.org/ nonproliferation-arms-control-and-disarmament/budapest-memorandums-security-assurances-1994/p32484 [sk. 27.03.2015.].

5. Felgenhauer, Tyler. WWS Case Study 2/99 Ukraine, Russia, and the Black Sea Fleet Accords, 1999. Iegūts no: http://dtic.mil/dtic/tr/fulltext/u2/a360381.pdf [sk. 29.03.2015.].

6. Putins stāsta par Krimas aneksijas operāciju; admirālis atzīst - to nodrošināja Melnās jūras flote, 2015. Iegūts no: http://www.sargs.lv/Zinas/Arvalstis/2015/03/16-02.aspx\#lastcomment [sk. 28.03.2015.].

7. Romas Starptautiskās krimināltiesas statūtu Starptautisks līgums, 2002. Latvijas Vēstnesis, 2002. g. 28. jūn.

8. The Alma-Ata Declaration, 1991. Iegūts no: http://www.cvce.eu/obj/alma_ata_declaration_alma_ata_21_december_1991-en-ffcd1505-481e-42f5-8293-c8089b125eb0.html [sk. 28.03.2015.].

9. Томсинов, В. А. «Крымское право» или юридические основания воссоединения Крыма с Россией. Москва: «Зеркало - М», 2015.

10. Указ Президента РФ от 17.03.2014 № 147 «О признании республики Крым». Iegūts no: http://news.kremlin.ru/acts/20596/print [sk. 27.03.2015.]. 